\title{
Rapeseed residue management for weed control and corn production
}

\author{
Mansour Sarajuoghi ${ }^{1 *}$, Saeed Mafakheri ${ }^{2}$, Raheleh Rostami ${ }^{3}$ and Masoumeh Shahbazi ${ }^{1}$ \\ ${ }^{1}$ Department of Agronomy, Borujerd Branch, Islamic Azad University, Borujerd, Iran \\ ${ }^{2}$ Young Researchers Club, Science and Research Branch, Islamic Azad University, Tehran, Iran \\ ${ }^{3}$ Young Researchers Club, Takestan Branch, Islamic Azad University, Takestan, Iran \\ ${ }^{*}$ msarajuoghi@gmail.com
}

\begin{abstract}
To study the effects of rapeseed residues on weeds growth and the following corn yield, this experiment was conducted in 2009 at Hamedan Agriculture Research Center, Iran. The experiment design was split plot in the form of a randomized complete block design with three replications. Treatments of the experiment were hand weeding (with and without) and rapeseed residues $(0,15$ and $30 \mathrm{~kg} / \mathrm{plot})$. Results indicated that hand weeding significantly affected all the measured traits of corn, but residue had only significant effect on plant height, ear diameter and 1000 kernels weight. Residue had also significant effect on weeds growth; the highest residue rate $(30 \mathrm{~kg} / \mathrm{plot})$ was more effective and gave the highest weed control.
\end{abstract}

Keywords: Allelopathy, Brassica napus, Residue, Weed, Zea mays.

\section{Introduction}

During the past decades, increased application of chemical herbicides has caused concerns about the effect of these materials on environment and products health. Moreover, the reliance of weed management on herbicides has increased the number and distribution of herbicide resistant weeds (Shanahan et al., 2003; Anonymous, 2010; Monaco et al., 2002). To overcome these problems, researchers are working to develop nonchemical weed management techniques and the integrated weed management.

One of the non-chemical methods is the application of allelopathic compounds instead of the chemically synthetic ones. These compounds are plant derived materials which suppers other plants. A more natural way to take advantages of allelopathy in weed control, in addition to the costly extraction from plant materials, is to put the allelopathic crop plants in rotation and incorporate their residues into soil or leave them on soil surface (Kohli et al., 2001; Kato-Noguchi, 2003; Putnam, 1988; Putnam \& Defrank, 1983). So many different plant species contain allelopathic compounds and their residues may have inhibitory effect on weeds. Rye (Secale cereale L.), sorghum (Sorghum bicolor L.), barley (Hordeum vulgare L.), cowpea (Vigna unguiculata L.) and different clovers (Trifolium spp.) are examples of these plants (Einhellig \& Souza, 1992; Hartwig \& Ammon, 2002; Teasdale et al., 2007; Malik et al., 2008) studied the effects of wild radish and rye cover crops and residues on weds and concluded that the two cover crops reduced the total weeds density by $35 \%$ and 50 , respectively. Mafakheri et al. (2010) also reported that rye cover crop residues controlled the total weeds density by about $28 \%$, at $4^{\text {th }}$ week after corn planting.

Rapeseed, in addition to being an important oil crop, is an allelopathic compounds containing plant. This crop has a valuable defense system called MyrosinaseGlucosinolate, which is an active allelopathic system
(Bones \& Rossiter, 1996). Studies indicate that incorporating rapeseed residues to soil (as cover crop or mulch) suppresses weed germination (Fenwick et al., 1983). These allelopathic materials may also affect germination of crops, especially those with small seeds. Moyer \& Huang (1997) reported that rapeseed aqueous extract reduced wheat germination compared with the control (distilled water). Regarding the importance of mulches and residues in non-chemical and integrated weed management, this study was conducted to evaluate the effects of rapeseed residues on weeds, and on yield of the following corn cultivation.

\section{Materials and methods}

This experiment was conducted in 2009 at Hamedan Agriculture Research Center, Iran $\left(51^{\circ} 48^{\prime} \mathrm{E}, 31^{\circ} 48 \mathrm{~N}\right.$, $1671 \mathrm{~m}$ above the sea level). The area is a mountainous, cold and semi arid region with average annual precipitation of about $309 \mathrm{~mm}$. The mean temperature of the warmest and the coldest month of the year are 23.66 and $2.3^{\circ} \mathrm{C}$, respectively. The soil type at the test site was loam with $\mathrm{pH}$ of 7.4 .

This study was conducted in a split plot experiment in the form of a randomized complete block design with three replications and two factors; 1 ). The main plots: with $\left(\mathrm{H}_{1}\right)$ and without $\left(\mathrm{H}_{0}\right)$ hand weeding, 2). The sub plots: three rapeseed residues rates as $0\left(R_{0}\right), 15\left(R_{15}\right)$ and 30 $\left(R_{30}\right) \mathrm{kg} / \mathrm{plot}$. Plots size was $13 \mathrm{~m}^{2}$.

After the field was prepared, rapeseed residues were left on soil and then corn seeds were planted. At the end of the growing season, corn yield and yield components were measured according to the standard method. Plant height was measured from the soil surface to the first branch of tassel. To measure the biologic yield (biomass), harvested plants were dried at $72^{\circ} \mathrm{C}$ in an oven for $48 \mathrm{~h}$. Then, weeds density was counted using a $1.5 \mathrm{~m} \times 1.5 \mathrm{~m}$ quadrate, weeds were harvested, oven dried and their dry weight was measured. The natural weed infestation at the time of sampling included Johnson grass (Sorghum 
Indian Journal of Science and Technology

Table 1. Analysis of the variances for corn yield and yield components

\begin{tabular}{|c|c|c|c|c|c|c|c|}
\hline \multirow[b]{2}{*}{ SOV } & \multirow[b]{2}{*}{ df } & \multicolumn{6}{|c|}{ Mean Squares (MS) } \\
\hline & & $\begin{array}{l}\text { Plant } \\
\text { height }\end{array}$ & $\begin{array}{l}\text { Ear } \\
\text { diameter }\end{array}$ & $\begin{array}{l}\text { Kernels } \\
\text { / row }\end{array}$ & $\begin{array}{l}1000 \\
\text { kernels } \\
\text { weight }\end{array}$ & $\begin{array}{l}\text { Grain } \\
\text { yield }\end{array}$ & $\begin{array}{l}\text { Biologic } \\
\text { yield }\end{array}$ \\
\hline Replication & 2 & $\mathrm{~ns}$ & * & ns & ns & $\mathrm{ns}$ & $\mathrm{ns}$ \\
\hline $\begin{array}{l}\text { Hand } \\
\text { weeding } \\
\text { (A) }\end{array}$ & 1 & ** & ** & ** & ** & ** & ** \\
\hline $\begin{array}{l}\text { Residue } \\
\text { (B) }\end{array}$ & 2 & ** & ** & ns & ** & ns & ns \\
\hline$A \times B$ & 2 & ** & ** & ns & $* *$ & ns & ns \\
\hline CV (\%) & - & 3.04 & 1.94 & 3.16 & 1.33 & 3.03 & 15.89 \\
\hline
\end{tabular}

ns, nonsignificant; ${ }^{* *}$, significant at $\mathrm{P} \leq 0.01$; ${ }^{*}$, significant at $\mathrm{P} \leq 0.05$.

Table 2. Effect of hand weeding, residues and their interaction on corn yield and yield components

\begin{tabular}{|c|c|c|c|c|c|c|}
\hline Treatments & $\begin{array}{l}\text { Plant } \\
\text { height } \\
(\mathrm{cm})\end{array}$ & $\begin{array}{c}\text { Ear } \\
\text { diameter } \\
(\mathrm{cm})\end{array}$ & $\begin{array}{c}\text { Kernels } \\
\text { / row }\end{array}$ & $\begin{array}{c}1000 \\
\text { kernels } \\
\text { weight } \\
(\mathrm{g})\end{array}$ & $\begin{array}{c}\text { Grain } \\
\text { yield } \\
\text { (ton/ha) }\end{array}$ & $\begin{array}{c}\text { Biologic } \\
\text { yield } \\
\text { (ton/ha) }\end{array}$ \\
\hline $\mathrm{H}_{1}$ & $192.27 a$ & $17.10 a$ & $44.71 a$ & $282.98 a$ & $14.71 a$ & $51.99 a$ \\
\hline $\mathrm{H}_{0}$ & $143.22 b$ & $16.01 \mathrm{~b}$ & $36.73 b$ & $240.90 b$ & $10.52 b$ & $38.64 b$ \\
\hline $\mathrm{R}_{0}$ & $160.58 b$ & $15.53 b$ & $39.66 a$ & $251.40 \mathrm{~b}$ & $12.36 a$ & $43.86 a$ \\
\hline $\mathrm{R}_{15}$ & 173.95a & $16.37 a$ & $40.66 a$ & $268.85 a$ & $12.70 \mathrm{a}$ & $45.61 a$ \\
\hline $\mathrm{R}_{30}$ & $170.20 \mathrm{a}$ & $16.26 a$ & $40.33 a$ & $265.57 a$ & $12.78 \mathrm{a}$ & $46.46 a$ \\
\hline $\mathrm{H}_{1} \mathrm{R}_{0}$ & $194.16 a$ & $17.01 a$ & $44.20 \mathrm{a}$ & $281.56 a$ & $14.33 a$ & $51.50 a$ \\
\hline $\mathrm{H}_{1} \mathrm{R}_{15}$ & 191.33a & $17.24 a$ & $44.66 a$ & $285.78 a$ & $14.83 a$ & $51.50 a$ \\
\hline $\mathrm{H}_{1} \mathrm{R}_{30}$ & 194.33a & $17.07 a$ & $43.26 a$ & $281.60 a$ & $14.96 a$ & $52.96 a$ \\
\hline $\mathrm{H}_{0} \mathrm{R}_{0}$ & $127.00 d$ & $14.05 c$ & $35.13 c$ & $221.25 c$ & $10.40 \mathrm{~b}$ & $36.23 c$ \\
\hline $\mathrm{H}_{0} \mathrm{R}_{15}$ & $156.38 b$ & $15.51 b$ & $37.66 \mathrm{~b}$ & $251.91 b$ & $10.56 b$ & $39.73 b$ \\
\hline $\mathrm{H}_{0} \mathrm{R}_{30}$ & $144.08 \mathrm{c}$ & $15.46 b$ & $37.40 \mathrm{~b}$ & $249.55 b$ & $10.60 b$ & $39.96 b$ \\
\hline
\end{tabular}

Table 3. Analysis of the variances for weeds density and biomass

\begin{tabular}{|c|c|c|c|c|c|}
\hline \multirow[b]{2}{*}{ SOV } & \multirow[b]{2}{*}{ df } & \multicolumn{4}{|c|}{ Mean Squares (MS) } \\
\hline & & $\begin{array}{c}\text { Total } \\
\text { biomass }\end{array}$ & $\begin{array}{c}S . \\
\text { halepense }\end{array}$ & $\begin{array}{c}A . \\
\text { retroflexus }\end{array}$ & Rumex spp \\
\hline Replication & 2 & ns & ns & ns & ns \\
\hline $\begin{array}{l}\text { Residue } \\
\text { (B) }\end{array}$ & 2 & * & ns & ** & ** \\
\hline CV (\%) & - & 13.48 & 17.93 & 7.61 & 9.70 \\
\hline
\end{tabular}

ns, nonsignificant; **, significant at $\mathrm{P} \leq 0.01$; ${ }^{*}$, significant at $\mathrm{P} \leq 0.05$.

halepense L.), Redroot pigweed (Amaranthus retroflexus

L.) and Sorrel (Rumex spp). Finally, data were analyzed using MSTAT-C and SPSS, and means were compared according to Duncan's multiple range test.

Results and discussion

\section{Corn yield and yield components}

Analysis of the variances indicated that hand weeding significantly affected all the measured traits $(P \leq 0.01$; Table 1). Hand weeding increased corn height by $34.25 \%, 1000$ kernels weight by $17.47 \%$ and grain yield by $39.83 \%$ and biologic yield by $34.55 \%$, compared with the control (Table 2). Hand weeding made the field free of weeds and removed the competition effect. This helped plants to grow well during the vegetative growth phase. Moreover, absence of weeds allowed plants to take advantages of light, water and nutrients; resulting in an
Vol. 5 No. 4 (Apr 2012)

ISSN: 0974- 6846

improved photosynthesis; the improved photosynthesis is responsible for increased corn yield and yield components.

Rapeseed residue had also a significant effect on plant height, ear diameter and 1000 kernels weight (Table 1). The effect of 15 and $30 \mathrm{~kg}$ residues/plot were the same on most of the measured traits (Table 2). Allelopathic residues have improved corn growth and yield through suppressing weeds; lower weed competition means higher crops growth and yield. Mafakheri et al. (2010) conducted an experiment to evaluate the effect of winter rye cover crop and mulch residues on the following corn cultivation and weeds infestation. They concluded that rye cover crop residues increased corn grain yield by $7.89 \%$ and plant height by $10.24 \%$. Vasilakoglou et al. (2006) also studied the effect of different cover crop residues on weeds and reported that at the third week after cotton cultivation, mulched treatments reduced germination of Setaria verticillata by $33-57 \%$ and Digitaria sanguinalis by $35-83 \%$, compared with the unmulched controls.

Weeds biomass and density

Results showed that rapeseed residues significantly affected the total weeds biomass and the density of Amaranthus retroflexus and Rumex spp (Table 3). Mean comparison indicated that $30 \mathrm{~kg}$ residues/ha reduced the total weeds biomass from 7.33 to $4.03 \mathrm{~kg} /$ plot. The difference of 15 and $30 \mathrm{~kg}$ residues/ha was no significant on the total weeds biomass, but was significant on the density of $A$. retroflexus and Rumex spp., (Table 4). These results indicate that higher residues rate is more effective on weeds control. The effect of residue rate on weed control is reported by other author. Teasdale \& Mohler (2000) reported that weed emergence declined when mulch rate increased. They also found that $A$. retroflexus emergence was even stimulated when mulch mass was lower than $2000 \mathrm{~kg} / \mathrm{ha}$. Treadwell et al. (2007) represented that weed density reduction is significantly correlated to cover crop residue dry weight.

Table 4. Effect of residues on weeds density and biomass

\begin{tabular}{|l|l|l|l|l|}
\hline \multirow{2}{*}{ Treatments } & $\begin{array}{c}\text { Biomass } \\
\text { (kg/plot) }\end{array}$ & \multicolumn{3}{|c|}{ Density } \\
\cline { 2 - 5 } & $\begin{array}{c}\text { Whole } \\
\text { weed } \\
\text { species }\end{array}$ & $\begin{array}{c}\text { S. } \\
\text { halepense }\end{array}$ & $\begin{array}{c}\text { A. } \\
\text { retroflexus }\end{array}$ & $\begin{array}{c}\text { Rumex } \\
\text { spp }\end{array}$ \\
\hline $\mathrm{R}_{0}$ & $7.33 \mathrm{a}$ & $5.00 \mathrm{a}$ & $10.07 \mathrm{a}$ & $4.83 \mathrm{a}$ \\
\hline $\mathrm{R}_{15}$ & $4.80 \mathrm{~b}$ & $5.33 \mathrm{a}$ & $2.67 \mathrm{~b}$ & $3.70 \mathrm{~b}$ \\
\hline $\mathrm{R}_{30}$ & $4.03 \mathrm{~b}$ & $4.57 \mathrm{a}$ & $1.00 \mathrm{c}$ & $1.57 \mathrm{c}$ \\
\hline
\end{tabular}

$R_{0}, 0 ; R_{15}, 15 ; R_{30}, 30 \mathrm{~kg}$ residues/plot.

Means in a column followed by the same letter are not significantly different at $\mathrm{P} \leq 0.01$.

Research article

CIndian Society for Education and Environment (iSee)
"Rapeseed residue \& weed control" http://www.indjst.org
M.Sarajuoghi et al. Indian J.Sci.Technol. 
Mafakheri et al. (2010) also reported that $3100-3350 \mathrm{~kg}$ rye residues/ha stimulated $A$. retroflexus biomass and increased it by $4.97 \%$, but $9700-10150 \mathrm{~kg}$ residues $/ \mathrm{ha}$ controlled and reduced the weed biomass by $19.30 \%$, compared with the control.

Mulches and residues control weeds through different mechanisms. The first mechanism is that mulches cover the soil surface and prevent light to reach the soil surface; lowering soil temperature. Presence of red light and warm environment is vital for weeds seeds germination, so mulches reduce weeds germination. Another mechanism is the exudation of allelopathic compounds (allelochemicals). Allelochemicals are plant defense system against other plants; they can be used as natural herbicides (Weston, 1996; Putnam, 1988; Xuan et al., 2005). Randhawa et al. (2002) studied the effect of sorghum water extract on germination and growth of a weed species ( Trianthema portulacastrum) and observed that the $100 \%$ concentration of the extract reduced the weed germination by $15-20 \%$. Finally, mulches and residues control weeds by affecting soil conditions and improvement of soil biological activity which results in the reduction of soil seed bank; the process is called seed predation. Shearin et al. (2008) reported that presence of cover crops and residues on soil surface promoted the activity of Harpalus rufipes beetles. This seed predator feeds on weed seeds in soil and results in the depletion of soil seed bank and lower seeds germination.

Conclusion

Results of this experiment indicated that rapeseed residues significantly affected weeds germination and growth; reducing the total weeds biomass to $4.03 \mathrm{~kg} / \mathrm{plot}$ from $7.33 \mathrm{~kg} /$ plot. Moreover, residues significantly increased corn height by $6 \%$, grain yield by $3.4 \%$ and biomass by $5.92 \%$ compared with the no residue control.

\section{References}

1. Anonymous (2010) International survey of herbicide resistant weeds, from http://www.weedscience.org. Accessed: Apr. 18, 2010.

2. Bones AM and Rossiter JT (1996) The MyrosinaseGlucosinolate system - an innate defense system in plants. Physiol Plantarum. 97(1), 194-208.

3. Einhellig FA and Souza IF (1992) Phytotoxicity of sorgoleone found in grain Sorghum root exudates. $J$. Chem. Ecol. 18(1), 1-11.

4. Fenwick GR, Heaney RK and Mullin WJ (1983) Glucosinolates and their breakdown products in food and food plants. Crit. Rev.Food Sci. \& Nutr.18 (2), 123-201.

5. Hartwig NL and Ammon HU (2002) Cover crops and living mulches. Weed Sci. 50, 688-699.

6. Kohli RK, Singh HP and Batish DR (2001) Allelopathy in Agroecosystems. Food Products Press, USA.

7. Mafakheri S, Ardakani MR, Meighani F, Mirhadi MJ and Vazan S (2010) Rye cover crop management affects weeds and yield of corn (Zea mays L.). Not. Bot. Hort. Agrobot. Cluj. 38(3), 117-123.
8. Malik MS, Norsworthy JK, Culpepper AS, Riley MB and Bridges Jr W (2008) Use of wild radish (Raphanus raphanistrum) and rye cover crops for weed suppression in sweet corn. Weed Sci. 56, 588-595.

9. Monaco TJ, Weller SC and FM Ashton (2002) Weed Science, $4^{\text {th }}$ ed: Principles and Practices. John Wiley \& Sons, USA.

10.Moyer JR and Huang HC (1997) Effect of aqueous extracts of crop residues on germination and seedling growth of ten weed species. Bot. Bull. Academia Sinica. 38, 131-139.

11.Putnam AR (1988) Allelochemicals from plants as herbicides. Weed Technol. 2(4), 510-518.

12.Putnam AR and DeFrank J (1983) Use of phytotoxic plant residues for selective weed control. Crop Protection. 2, 173-181.

13.Randhawa MA, Cheema ZA and Ali MA (2002) Allelopathic effect of sorghum water extract on the germination and seedling growth of Trianthema portulacastrum. Int. J. Agri \& Biol. 4(3), 383-384.

14. Shanahan M, Jordan C, Trent S and Williams J (2003) What's your poison? From Environmental justice Foundation: http://www.ejfoundation.org. Accessed: Jan. 7, 2008.

15.Shearin AF, Reberg-Horton SC and Gallandt ER (2008) Cover crop effects on the activity-density of the weed seed predator Harpalus rufipes (Coleoptera: Carabidae). Weed Sci. 56, 442-450.

16. Teasdale JR and Mohler CL (2000) The quantitative relationship between weed emergence and the physical properties of mulches. Weed Sci. 48, 385392.

17.Teasdale JR, Brandsaeter LO, Calegari A and Skora Neto $F(2007)$ Cover crops and weed management. In: Non-Chemical Weed Management: Principles, Concepts and Technology (eds. Upadhyaya MK \& Blackshaw RE), pp. 49-64. CABI Publ., UK.

18. Treadwell DD, Creamer NG, Schultheis JR and Hoyt GD (2007) Cover crop management affects weeds and yield in organically managed sweetpotato systems. Weed Technol. 21, 1039-1048.

19.Vasilakoglou I, Dhima K, Eleftherohorinos I and Lithourgidis A (2006) Winter cereal cover crop mulches and inter-row cultivation effects on cotton development and grass weed suppression. Agronomy J. 98, 1290-1297.

20.Weston LA (1996) Utilization of allelopathy for weed management in agroecosystems. Agronomy J. 88, 860-866.

21.Xuan TD, Shinkichi T, Khanh TD and Chung IM (2005) Biological control of weeds and plant pathogens in paddy rice by exploiting plant allelopathy. Crop Protect. 24(3), 197-206.
Research article

CIndian Society for Education and Environment (iSee)
"Rapeseed residue \& weed control" http://www.indjst.org
M.Sarajuoghi et al. Indian J.Sci.Technol. 